\title{
Correlation Between Writing Skills, High Frequency Lexicon Mastery and Students' Reading Skills at SMP Negeri 1 Rambang, Muara Enim
}

\author{
Maulana Idris ${ }^{1 *}$, Rusman Roni ${ }^{2}$, Artanti Puspita Sari ${ }^{2}$ \\ ${ }^{1}$ SMP Negeri 1 Rambang in Muara Enim \\ ${ }^{2}$ Universitas PGRI Palembang \\ Corresponding author Email bundaayahilal@gmail.com
}

\begin{abstract}
This study aims to determine the correlation between writing skills, high frequency lexicon mastery, and reading skills at SMP Negeri 1 Rambang. This study used descriptive method and statistical analysis. This study's population was all the eighth-grade students of SMP Negeri 1 Rambang which were contributed into four classes. The total population is 119 students. The sample was taken randomly, $25 \%$ of the population. The total number of samples was 40 students. Based on data analysis, there is relationship between writing skills, high-frequency lexicon mastery and reading skill at SMP Negeri 1 Rambang $\left(\mathrm{r}\right.$ table $<\mathrm{r}_{\mathrm{xy}}=0.220<0.66$. It showed that the students who got good marks at reading tests also got good marks at writing tests. It could be concluded that there is writing skills, high frequency lexicon mastery and reading skills of the eighth grade of SMP Negeri 1 Rambang in the academic year of $2020 / 2021$
\end{abstract}

Keywords: Correlation, Writing Skill, High frequency lexicon, Reading Skill

\section{INTRODUCTION}

English has been selected as the universal language and is one of the languages in the world. Furthermore, one kind of medium for oral and written communication is English. Communication means understanding and demonstrating the data, thinking, felling, and developing science [1]. The government said that the national aims to sharpen the lives of people and promote the standard of education. This curriculum is specified that English is a mandatory subject in primary school, junior high school, and senior high school and in freshmen classes as well [2]. Moreover, the program suggests that junior high school students learn English from the first year of school.

Opportunity to learn English. It is not easy to learn English as a language. Currently, in mastering English, Indonesian students who study English also find some difficulties. Some Indonesian learners find it difficult to master English because the structure of English is not familiar to some Indonesian students. In Indonesia, English is a foreign language, so English students in Indonesia are foreign language learners.
Another theory is that English and Indonesian are two distinct languages with distinct sound systems, vocabulary, structures, and cultures [2]. Indonesian students who learn English must seriously and consistently study English.

Reading is the first language skill students can learn before they master the other language skills. Reading is the ability to articulate written words in English sounds and comprehend what is being read. Reading concerns not only the assignment of English sounds to the words, but also the comprehension of what is written [3].

Communicative strategies in using a language learning do not only include spoken language, but also involve using written language to create spoken and written communication. Spoken language deals with listening and speaking skills of the language. On the other hand, written language deals with literacy skills i.e. reading and writing skills of language [1].

Communication means to understand and to show the information, think, felling, and develop science. One of the language competencies that has 
important role is reading. This competence is acquired to develop understanding about other's idea through a book or writing form. By reading, students are able to observe the idea given by the writing. This skill is able to help them find out the new idea by their critical thinking. In reading activities, the teacher should train students to know the meanings of the words, find general and specific information to get the ideas from the text and guide students to find synonyms, antonyms, and reference words.

\section{METHODS}

This research was quantitative research with a correlation research design. The correlations among $\mathrm{X} 1, \mathrm{X} 2$, and $\mathrm{Y}$ were deliberated. Case studies, casualcomparative and correlation research that are considered as non-experimental studies are also called descriptive research [4]. The goal is to create a description, link, image or painting in a systematic, factual, and accurate manner as to facts and the properties of the relationship between the phenomenon's under investigation [5].

We have two independent variables; writing skills and High Frequency Lexicon Mastery. The dependent variable is reading skills. The population of this study was taken from all of the eighth grades of SMP NEgeri 1 Rambang in the academic year of $2020 / 2021$. The data of the population of study can be seen in the Table 1.

Table 1. Population of the Study

\begin{tabular}{ccccc}
\hline & & \multicolumn{2}{c}{ Students } & \multirow{2}{*}{ Total } \\
\cline { 3 - 4 } No. & Class & Boy & Girl & \\
\hline & & & & \\
1 & $8 \mathrm{a}$ & 13 & 17 & 30 \\
2 & $8 \mathrm{~b}$ & 13 & 17 & 30 \\
3 & $8 \mathrm{c}$ & 14 & 15 & 29 \\
4 & $8 \mathrm{~d}$ & 14 & 16 & 30 \\
\hline
\end{tabular}

\section{Total number of students}

119

(Source: SMPN I Rambang in academic year 2020-2021)

If the subject in population less than $(<100)$, it is suggested to take it all. But, if the population is a big number, We can take the number of students between $10-15 \%$ or $20-25 \%$ or more [4]. This study's population was 119 from 4 classes, so the writer took over $20 \%$ of population as the sample. It meant we used ten students for each class, with one hundred and seventeen students treated as the sample later since every member of the population has an equal opportunity to participate.

\section{RESULTS AND DISCUSSION}

To measure the students' writing skills, the researcher distributed a questionnaire consisting of 20 items in the form. It can be seen that there no student or $0 \%$ who got interval score $89-120,26$ students or $41 \%$ who got interval score 57 - 88, 37 students or $59 \%$ who got interval score $24-56$. It means students of the eighth grade students of SMPN I Rambang tend to be more passive to write, find out in the text, and individual.

To measure the students' high frequency lexicon mastery, the researcher also gave questions consisting of 20 items. It was found that 8 students or $13 \%$ got interval score $77-95,38$ students or $60 \%$ got interval score $58-76,14$ students or $22 \%$ got interval score $39-57$, and 3 students or $5 \%$ got interval score $19-38$ in high frequency lexicon mastery.

The reading test data is determined from the students' responses in the responses in the test of spoken English that were rated by two raters. The writer had recorded their scores and compared scores to see if their scores are similar or different. And the results of both raters have similarities in scoring, so the writer got the final score from the middle score.

Based on Pearson Product Moment correlation, the result of correlation analysis between writing skills, high-frequency lexicon mastery, and reading skills, there is relationship between writing skills, high-frequency lexicon mastery and reading skill at SMP Negeri 1 Rambang ( $\mathrm{r}$ table $<\mathrm{r}_{\mathrm{xy}}=$ $0.220<0.66$ ). Learning English as a second language learning is closely related to the rich vocabulary of students [6][7]. There are several studies which state that there is a very significant relationship between lexical knowledge and skills in writing, reading, speaking, and listening [8][9]. Therefore, learning English is very important using lexical knowledge [10].

\section{CONCLUSION}

Based on the resut and discussion, we can conclude that there is relationship between writing skills, high-frequency lexicon mastery and reading skill at SMP Negeri 1 Rambang.

\section{REFERENCES}

[1] Morreale, S. P., Osborn, M. M., \& Pearson, J. C. (2000). Why communication is important: A rationale for the centrality of the study of communication. JACA-ANNANDALE-, 1, 125. 
[2] Saukah, A. (2003). Pengajaran bahasa Inggris di Indonesia: Tinjauan terhadap unjuk kerja pembelajar serta upaya peningkatannya. Malang, Indonesia: Departemen Pendiddikan NasionalUniversitas Negeri Malang.

[3] Saleh, Y. (1982). Method of Teaching English as a Foreign Language. Palembang: University of Sriwijaya.

[4] Arikunto, S. (2002). Prosedur Penelitian Suatu Pendekatan Praktek, Jakarta; Bina Aksara.

[5] Creswell, J. W. (2012). Educational research: Planning, conducting, and evaluating quantitative and qualitative research $\left(4^{\text {th }} \mathrm{ed}\right)$. Boston, MA: Pearson Education, Inc.

[6] Beglar, D., \& Hunt, A. (2005). Six principles for teaching foreign language vocabulary. The Language Teacher, 29(7), 7-10.
[7] Nation, I. S. P. (2013). Learning vocabulary in another language. Cambridge: Cambridge University Press.

[8] Milton, J., Wade, J., \& Hopkins, N. (2010). Aural word recognition and oral competence in English as a foreign language. In R. ChacónBeltrán, C. Abello-Contesse, and M. Torreblanca-López (Eds.), Insights into nonnative vocabulary teaching and learning (pp. 83-98). Bristol: Multilingual Matters.

[9] Stæhr, L. S. (2008). Vocabulary size and the skills of listening, reading and writing. Language Learning Journal 36(2), 139-152. doi:10.1080/09571730802389975

[10] Qian, D. D. (2002). Investigating the relationship between vocabulary knowledge and academic reading performance: An assessment perspective. Language Learning, 52(3), 513-536. doi:10.1111/1467-9922.00193 